\title{
Evaluation of selected South African ethnomedicinal plants as mosquito repellents against the Anopheles arabiensis mosquito in a rodent model
}

\author{
Rajendra Maharaj ${ }^{1 *}$, Vinesh Maharaj ${ }^{2}$, Marion Newmarch, Neil R Crouch ${ }^{3}$, Niresh Bhagwandin ${ }^{4}$, Peter I Folb ${ }^{4}$, \\ Pamisha Pillay', Reshma Gayaram¹
}

\begin{abstract}
Background: This study was initiated to establish whether any South African ethnomedicinal plants (indigenous or exotic), that have been reported to be used traditionally to repel or kill mosquitoes, exhibit effective mosquito repellent properties.

Methods: Extracts of a selection of South African taxa were tested for repellency properties in an applicable mosquito feeding-probing assay using unfed female Anopheles arabiensis.

Results: Although a water extract of the roots of Chenopodium opulifolium was found to be $97 \%$ as effective as DEET after 2 mins, time lag studies revealed a substantial reduction in efficacy (to 30\%) within two hours.
\end{abstract}

Conclusions: None of the plant extracts investigated exhibited residual repellencies $>60 \%$ after three hours.

\section{Background}

Despite ongoing efforts to control the disease, malaria still remains a serious public health problem in about 90 countries worldwide. On a global scale, malaria causes 300-500 million cases and results in 1.5-3 million deaths annually. Of these, approximately $80 \%$ of cases occur on the African continent. In the Southern Africa Development Community (SADC) mortality ranges from 0 to 128 per 100,000 population [1].

This large-scale threat to human health is transmitted by anopheline mosquitoes. These vectors feed between dusk and dawn, mostly inside houses whilst residents are asleep. However, due to behaviour modification by both vector and host, mosquitoes increasingly feed outdoors, so avoiding the insecticides sprayed on inner walls of houses in the course of vector control programmes [2].

\footnotetext{
* Correspondence: rmaharaj@mrc.ac.za

'South African Medical Research Council, 491 Ridge Road, Overport, Durban 4001, South Africa

Full list of author information is available at the end of the article
}

In order to provide protection to target individuals who are outdoors during the period of active feeding, repellents are used. Repellents are applied to exposed skin, especially the arms and legs, to protect individuals against mosquitoes seeking a blood meal. The most successful active ingredient of several skin-applied mosquito repellent products is N,N-diethyl-meta-toluamide (DEET) [3]. Although presently highly effective, there have been some concerns of DEET's adverse side effects when used in high concentrations [4]. In southern Africa, limited work has been conducted on the search for natural repellent products. Although the value of numerous synthetic compounds have been investigated for repellency against Anopheles gambiae [5], there have been very few studies investigating the use of plant-derived chemicals as repellents of vectors of malaria.

Apart from employing antiplasmodials [6] and insecticidal interventions, communities in Africa have historically employed traditional methods to ward off bothersome mosquitoes, even if the association between malaria and this vector has not been made. Different methods include burning of cow dung or certain plants, or the placement
Ciomed Central

C 2010 Maharaj et al; licensee BioMed Central Ltd. This is an Open Access article distributed under the terms of the Creative Commons Attribution License (http://creativecommons.org/licenses/by/2.0), which permits unrestricted use, distribution, and reproduction in any medium, provided the original work is properly cited. 
of specific plant parts in and around the sleeping area. Plants have long been recognized as having insect repellent properties. In endemic malaria areas, plants have been crushed or used whole to provide protection against mosquitoes [7], or burned to this effect [8].

As part of a national programme to identify new products from medicinal plants to combat malaria, this study was initiated to establish whether any indigenous or naturalized South African ethnomedicinal plants that have been reportedly used traditionally to repel or kill mosquitoes exhibit effective mosquito repellent properties. Accordingly, extracts of a selection of a number of such taxa were tested for their mosquito repellency properties in a suitable bioassay, which assesses the potency of the test substance when applied topically to the skin.

\section{Methods}

\section{Selection and collection of plant material}

A survey of relevant literature on ethnomedicinal plants used in East and Southern Africa revealed that a number of taxa have been reported to be used as mosquito repellents, or to repel or kill other invertebrates. However, given the limited quality of documented data available, it was decided to not make a distinction between insect repellents and insecticides (both larva- and adulticides), but to rather consider a pool of plants with antiinsecticidal activity. This decision was in part based on earlier observations [9] that some plants possessing repellent properties are also insecticidal. The converse could be true. In order to select the most relevant taxa, all were ranked following the application of weighted criteria, principally ethnobotanical and chemotaxonomic (including such elements as popularity in ethnomedicinal trade, reports on insecticidal and/or mosquitocidal application, reports on insect and/or mosquito repellent application, and the known presence and diversity of repellent/insecticidal constituents in the family to which it belongs). Higher weighting was provided to plants indigenous to the Flora of southern Africa region. A similar semi-quantitative selection method has previously been applied to identify and rank anti-plasmodial plant candidates from South Africa [6].

From the ranked list selected plants were collected throughout South Africa. Different plant parts, namely, leaves, root, stem, fruit, flowers, seeds, twigs and bark, and combinations of the above were sourced to generate extracts. In some instances, extracts were made of the whole plant. The plant organ(s) selected for extract preparation was based largely on availability at the time of collection.

The identity of plant material was determined at the National Herbarium of South Africa (PRE) where voucher specimens have been lodged.

\section{Extract preparation}

Plant samples were separated into different components and dried in an oven at $30-60^{\circ} \mathrm{C}$. The drying time and temperature varied depending on the nature of the plant part. Dried plant material was ground to a coarse powder using a hammer mill and stored at ambient temperature prior to extraction. For each extraction procedure, 100$500 \mathrm{~g}$ of powdered plant material was sequentially extracted, with cold dichloromethane (DCM), DCM/ methanol $(\mathrm{MeOH})(1: 1), \mathrm{MeOH}$ and purified water. Organic extracts were concentrated by rotary vacuum evaporation below $45^{\circ} \mathrm{C}$ and then further dried in vacuo at ambient temperature for $24 \mathrm{~h}$. The aqueous extracts were concentrated by freeze-drying. All dried extracts were stored at $-20^{\circ} \mathrm{C}$.

\section{Animal preparation}

Repellent activity was assessed by topical application of the test substance to the ventral surface of test rodents, and subsequent exposure of the treated area to unfed female mosquitoes. The number of bites relative to the untreated negative control was recorded, and the repellency percentage determined. The standard WHO guidelines were adapted for use in this trial [10].

The rodent, Mastomys coucha was used for the screening of the extracts. Ethical approval for the use of live animals in this study was obtained from the Ethics Committee of the South African Medical Research Council. Animals were put into groups of four, and each plant extract was tested on two animals, whilst the remaining two animals were used as negative and positive controls respectively. Carriers for the extracts, either acetone or distilled water, were used as the untreated negative control whereas concentrated, laboratory grade DEET was used as the positive control. Crude plant samples were dissolved in either acetone or distilled water depending on their initial extraction procedure thus forming a $10 \mathrm{mg} / \mathrm{ml}$ solution. DCM and DCM/MeOH extracts were reconstituted in acetone whereas aqueous extracts were made up in distilled water.

Adult rodents were weighed individually, and injected intraperitoneally with a $1 \mathrm{ml}$ solution of sodium pentobarbital $(60 \mathrm{mg} / \mathrm{l})$ per $0.225 \mathrm{~kg}$ of body weight. Once anaesthetized, rodents were shaved on the ventral surface and $1 \mathrm{ml}$ of plant extract solution applied to the abdomens of each of two rodents. The percentage repellency was taken as the mean of the number of bites relative to the untreated negative control.

\section{Probing activity assay}

Paper cups $(500 \mathrm{ml})$ were modified by replacing the base of the cup with mosquito netting held in place with a rubber band and covering the mouth of the cup with transparent plastic film. Thirty unfed 4-day old Anopheles 
arabiensis females were introduced into the cup and held in contact with the treated ventral surface of each anaesthetized rodent. Mosquito activity was observed through the transparent plastic film. At the end of a two-minute exposure period the number of mosquitoes probing (attempting to feed on the anaesthetized mouse, through the netting) was recorded. For those extracts with protection $>80 \%$ after 2 mins, the repellency effect was determined hourly for up to three hours post application. The rodent was then returned to the animal facility and allowed to recover from the anaesthetic.

\section{Results and discussion}

A total of 115 plant extracts, derived from 24 taxa representing 14 plant families, were evaluated for their repellency properties, (Table 1). Results have been presented alphabetically by family, genus and species, and thereafter in descending order of repellency effect after the two-minute exposure period.

Stringent criteria were used to assess the biological activity, in order to determine their potential as plantderived repellents. Since these were crude plant extracts, a mosquito repellency effect of $80 \%$ was considered significant for further investigation. Seven samples from seven taxa showed $\geq 80 \%$ repellency, whereas the remaining 109 samples gave between 15 and $76 \%$ efficacy relative to the negative control. However, a repellent is only effective if it has a long-lasting effect. Since DEET is known to have an eight hour effect, for the purposes of these investigations, substantial repellency $(>80 \%)$ after three hours was taken to be an indication of high activity worth of further investigation. To ensure that the highly active extracts maintained a constant repellent effect over a period of three hours, five of the seven samples indicating repellency ranging from 83 to $97 \%$ were subjected to a time lag trial (Table 2). This further evaluation was deemed an important requirement in considering their further industrial development, as market competitors of DEET should necessarily exhibit repellency over an extended period.

From the time lag studies, it was found that postapplication, the most active extracts rapidly lost activity. Compared to the positive control, DEET, these extracts were not long-lasting.

None of the extracts satisfied the $80 \%$ repellent activity cut off point after three hours. The most active species, Chenopodium opulifolium (Chenopodiaceae) was found only $30 \%$ effective relative to the negative control after three hours post application (Table 2). However, as only crude extracts were assayed in all repellency trials it is possible that active constituents isolated from roots of C. opulifolium could show prolonged repellency.

In considering the plant families used in this study, two of the seven most active extracts belong to the Asteraceae family. Artemisia absinthium has been shown to possess tick repellent properties [9]; the authors found that this plant synthesized volatiles that exhibited insecticidal properties. Previous studies have shown that plants belonging to the Fabaceae $[11,12]$ are noted for their larvicidal activity. Park et al [13] found that monoterpenes from the Lamiaceae could be used to repel mosquitoes of the genus Culex, Similarly, octacosane derived from Moschosma polystachyum (Lamiaceae) was effective in repelling Culex [14].

Globally, an enormous amount of work has been completed in trying to develop mosquitocidal compounds from plants. The use of plants as larvicides or adulticides is not a novel concept. A number of the insecticides currently used for malaria control are products of plants [15]. Limited research has been completed on the search for natural repellent products Apium graveolens (Apiaceae) is capable of repelling Aedes, Anopheles and Mansonia species [16], whilst the essential oils of ginger, Zingiber officinale (Zingiberaceae) and rosemary, Rosmarinus officinalis (Lamiaceae) were found to be repellent towards Anopheles stephensi, Aedes aegypti and Culex quinquefasciatus [17]. However, whilst in these reports the percentage of mosquitoes repelled were lower than observed in most plants reported in the present study, the longevity of effect was greater. Nevertheless, these studies used vectors that are not found in southern Africa.

A study conducted in western Kenya [8] has shown limited efficacy of traditionally used mosquito repellents; plants were either burnt or used whole, resulting in a maximum repellency effect of $52 \%$ against An. gambiae.

Numerous studies have been completed where chemicals have been tested for repellency effect against $A n$. gambiae [18,19]. There is limited information available on the use of plant-derived chemicals as repellents of mosquitoes, especially An. gambiae.

Although all extracts demonstrated some bioactivity (15-97\%), none of the extracts tested displayed repellency comparable to DEET after a prolonged period. Even though cognisance was taken of the fact that these were crude plant extracts none of them exceeded the minimum acceptable repellency level (80\%) during time lag studies. Organic extracts of the plants in general showed more potent repellency relative to their corresponding aqueous extract. This indicates that the lower molecular weight compounds may be contributing to the repellency properties rather than the macromolecules generally found in aqueous based extracts. Exceptions were the three species Eclipta prostrata (Asteraceae), Chenopodium opulifolium (Chenopodiaceae) and Plectranthus laxiflorus (Lamiaceae), where water extracts were found more potent than their corresponding organic extracts. A further noticeable trend was that the extracts of leaves showed better repellency than extracts of other plant 
Table 1 Two minute mosquito repellency screening results for extracts of South African ethnomedicinal plants

\begin{tabular}{|c|c|c|c|c|c|}
\hline Family & Plant species & $\begin{array}{l}\text { Voucher } \\
\text { number }\end{array}$ & Plant Part & Extraction & $\begin{array}{l}\text { Repellency } \\
\text { (\%) }\end{array}$ \\
\hline \multirow[t]{3}{*}{ Apiaceae } & Apiaceae & EN00994 & Whole plant & $\begin{array}{l}\mathrm{DCM} / \mathrm{MeOH} \\
(1: 1)\end{array}$ & 55 \\
\hline & Alepidea amatymbica Eckl. \& Zeyh. & & & & \\
\hline & & & Whole plant & Water & 23 \\
\hline \multirow[t]{22}{*}{ Asphodelaceae } & $\begin{array}{l}\text { Aloe greatheadii Schönland var. davyana (Schönland) } \\
\text { Glen \& D.S. Hardy }\end{array}$ & EN00021 & Leaves & DCM & 55 \\
\hline & & EN00021 & Leaves & $\begin{array}{l}\text { DCM/MeOH } \\
(1: 1)\end{array}$ & 55 \\
\hline & & EN00021 & Stem & $\mathrm{DCM}$ & 53 \\
\hline & & EN00021 & Leaves & Water & 43 \\
\hline & & EN00021 & Leaves & DCM & 36 \\
\hline & & EN00021 & Stems & $\begin{array}{l}\mathrm{DCM} / \mathrm{MeOH} \\
(1: 1)\end{array}$ & 33 \\
\hline & & EN00021 & Stems & $\mathrm{MeOH}$ & 31 \\
\hline & & EN00021 & Stems & Water & 27 \\
\hline & Aloe ferox Mill. & EN00538 & Fruit & DCM & 68 \\
\hline & & BP00469 & Whole plant & $\begin{array}{l}\mathrm{DCM} / \mathrm{MeOH} \\
(1: 1)\end{array}$ & 58 \\
\hline & & EN00538 & Roots & $\mathrm{DCM}$ & 56 \\
\hline & & EN00538 & Stem & $\begin{array}{l}\mathrm{DCM} / \mathrm{MeOH} \\
(1: 1)\end{array}$ & 52 \\
\hline & & EN00538 & Roots & $\begin{array}{l}\mathrm{DCM} / \mathrm{MeOH} \\
(1: 1)\end{array}$ & 50 \\
\hline & & EN00538 & Leaves & $\begin{array}{l}\text { DCM/MeOH } \\
(1: 1)\end{array}$ & 40 \\
\hline & & EN00538 & Leaves & $\mathrm{DCM}$ & 33 \\
\hline & & EN00538 & Stems & DCM & 33 \\
\hline & & EN00538 & Roots & Water & 31 \\
\hline & & EN00538 & Stems & Water & 31 \\
\hline & & BP00469 & Whole plant & Water & 30 \\
\hline & & EN00538 & Fruit & Water & 26 \\
\hline & & EN00538 & Leaves & Water & 26 \\
\hline & & EN00538 & Fruit & $\begin{array}{l}\text { DCM/MeOH } \\
(1: 1)\end{array}$ & 21 \\
\hline \multirow[t]{16}{*}{ Asteraceae } & *Bidens pilosa L. & EN00001 & Leaves & $\begin{array}{l}\mathrm{DCM} / \mathrm{MeOH} \\
(1: 1)\end{array}$ & 43 \\
\hline & & EN00001 & Leaves & $\mathrm{DCM}$ & 40 \\
\hline & & EN00001 & Leaves & Water & 31 \\
\hline & & EN00001 & Leaves & $\mathrm{MeOH}$ & 30 \\
\hline & ${ }^{*}$ Chromolaena odorata (L.) R.M.King \& H.Rob. & EN00052 & Leaves & $\mathrm{MeOH}$ & 80 \\
\hline & & EN00052 & Leaves & DCM & 76 \\
\hline & & EN00052 & Whole plant & $\mathrm{MeOH}$ & 68 \\
\hline & & EN00052 & Leaves & $\begin{array}{l}\mathrm{DCM} / \mathrm{MeOH} \\
(1: 1)\end{array}$ & 67 \\
\hline & & EN00052 & Whole plant & $\mathrm{DCM}$ & 61 \\
\hline & & EN00052 & Whole plant & $\begin{array}{l}\mathrm{DCM} / \mathrm{MeOH} \\
(1: 1)\end{array}$ & 57 \\
\hline & & EN00052 & Flowers & $\mathrm{MeOH}$ & 50 \\
\hline & & EN00052 & Leaves & Water & 46 \\
\hline & & EN00052 & Whole plant & Water & 31 \\
\hline & & EN00052 & Flowers & Water & 25 \\
\hline & & EN00052 & Flowers & $\mathrm{DCM}$ & 18 \\
\hline & & EN00052 & Flowers & $\begin{array}{l}\mathrm{DCM} / \mathrm{MeOH} \\
(1: 1)\end{array}$ & 15 \\
\hline
\end{tabular}


Table 1 Two minute mosquito repellency screening results for extracts of South African ethnomedicinal plants (Continued)

\begin{tabular}{|c|c|c|c|c|c|}
\hline & ${ }^{*}$ Eclipta prostrata (L.) L. & DS00616 & Whole plant & Water & 67 \\
\hline & & DS00616 & Whole plant & $\begin{array}{l}\mathrm{DCM} / \mathrm{MeOH} \\
(1: 1)\end{array}$ & 20 \\
\hline & Litogyne gariepina (DC.) Anderb. & EN00213 & Roots & DCM & 83 \\
\hline & & EN00213 & Roots & Water & 30 \\
\hline & & EN00213 & Roots & $\begin{array}{l}\mathrm{DCM} / \mathrm{MeOH} \\
(1: 1)\end{array}$ & 28 \\
\hline \multirow[t]{2}{*}{ Buddlejaceae } & Nuxia floribunda Benth. & BP00669 & Leaves & $\begin{array}{l}\mathrm{DCM} / \mathrm{MeOH} \\
(1: 1)\end{array}$ & 85 \\
\hline & & & Leaves & Water & 28 \\
\hline \multirow[t]{9}{*}{ Chenopodiacae } & ${ }^{*}$ Chenopodium ambrosioides L. & BP00545 & Leaves & $\begin{array}{l}\mathrm{DCM} / \mathrm{MeOH} \\
(1: 1)\end{array}$ & 87 \\
\hline & & BP00545 & Twigs & $\begin{array}{l}\mathrm{DCM} / \mathrm{MeOH} \\
(1: 1)\end{array}$ & 31 \\
\hline & & BP00545 & Leaves & $\begin{array}{l}\mathrm{DCM} / \mathrm{MeOH} \\
(1: 1)\end{array}$ & 25 \\
\hline & ${ }^{*}$ Chenopodium opulifolium Schrad. ex W.D.J.Koch \& Ziz & DS00390 & Roots & Water & 97 \\
\hline & & DS00390 & Stems & Water & 67 \\
\hline & & DS00390 & Roots & $\begin{array}{l}\mathrm{DCM} / \mathrm{MeOH} \\
(1: 1)\end{array}$ & 33 \\
\hline & & DS00390 & Leaves & $\begin{array}{l}\mathrm{DCM} / \mathrm{MeOH} \\
(1: 1)\end{array}$ & 33 \\
\hline & & DS00390 & Stems & $\begin{array}{l}\mathrm{DCM} / \mathrm{MeOH} \\
(1: 1)\end{array}$ & 30 \\
\hline & & DS00390 & Leaves & Water & 20 \\
\hline \multirow[t]{6}{*}{ Euphorbiaceae } & Croton pseudopulchellus Pax & HV00052 & Leaves & $\begin{array}{l}\mathrm{DCM} / \mathrm{MeOH} \\
(1: 1)\end{array}$ & 33 \\
\hline & & HV00052 & Leaves & Water & 25 \\
\hline & Spirostachys africana Sond. & EN00346 & Stems & $\begin{array}{l}\mathrm{DCM} / \mathrm{MeOH} \\
(1: 1)\end{array}$ & 48 \\
\hline & & EN00346 & Stems & Water & 33 \\
\hline & & EN00346 & Stems & DCM & 28 \\
\hline & & BP00230 & $\begin{array}{l}\text { Leaves and } \\
\text { twigs }\end{array}$ & $\begin{array}{l}\mathrm{DCM} / \mathrm{MeOH} \\
(1: 1)\end{array}$ & 18 \\
\hline \multirow[t]{15}{*}{ Fabaceae } & $\begin{array}{l}\text { Dichrostachys cinerea (L.) Wright \& Arn. subsp. africana Brenan \& } \\
\text { Brummitt }\end{array}$ & EN00101 & Leaves & $\mathrm{MeOH}$ & 67 \\
\hline & & EN00101 & Stems & $\begin{array}{l}\text { DCM/MeOH } \\
(1: 1)\end{array}$ & 65 \\
\hline & & EN00101 & Stems & DCM & 50 \\
\hline & & EN00101 & Leaves & Water & 46 \\
\hline & & EN00101 & Stems & Water & 33 \\
\hline & & EN00101 & Leaves & $\begin{array}{l}\mathrm{DCM} / \mathrm{MeOH} \\
(1: 1)\end{array}$ & 33 \\
\hline & & EN00101 & Leaves & DCM & 28 \\
\hline & Mundulea sericea (Willd.) A.Chev. & BP00043 & Leaves & $\begin{array}{l}\mathrm{DCM} / \mathrm{MeOH} \\
(1: 1)\end{array}$ & 76 \\
\hline & & BP00043 & Leaves & DCM & 72 \\
\hline & & BP00043 & Leaves & $\mathrm{MeOH}$ & 48 \\
\hline & & BP00043 & Leaves & Water & 26 \\
\hline & $\begin{array}{l}\text { Philenoptera violacea (Klotzsch) Schrire (syn. } \\
\text { Lonchocarpus capassa Rolfe) }\end{array}$ & MM00019 & Stems & DCM & 55 \\
\hline & & MM00019 & Leaves & $\begin{array}{l}\mathrm{DCM} / \mathrm{MeOH} \\
(1: 1)\end{array}$ & 31 \\
\hline & & MM00019 & Stems & Water & 30 \\
\hline & & MM00019 & Leaves & $\begin{array}{l}\mathrm{DCM} / \mathrm{MeOH} \\
(1: 1)\end{array}$ & 30 \\
\hline
\end{tabular}


Table 1 Two minute mosquito repellency screening results for extracts of South African ethnomedicinal plants (Continued)

Lamiaceae L Leucas martinicensis (Jacq.) R.Br.

Mentha longifolia (L.) Huds.

Plectranthus laxiflorus Benth.

Malvaceae Sida cordifolia L.

Meliaceae $\quad *$ Melia azedarach L.

Pedaliaceae Ceratotheca triloba (Bernh.) Hook.f.

Rutaceae Clausena anisata (Willd.) Hook.f. ex Benth.

*Datura stramonium L.

Vitaceae Cissus cornifolia (Baker) Planch.
Solanaceae

\begin{tabular}{|c|c|c|c|}
\hline MM00019 & Seeds & Water & 28 \\
\hline MM00019 & Roots & $\begin{array}{l}\text { DCM/MeOH } \\
(1: 1)\end{array}$ & 28 \\
\hline MM00019 & Leaves & Water & 27 \\
\hline MM00019 & Bark & DCM/MeOH & 26 \\
\hline MM00019 & Roots & Water & 21 \\
\hline MM00019 & Bark & Water & 20 \\
\hline EN00183 & Leaves & DCM & 86 \\
\hline EN00183 & Leaves & $\begin{array}{l}\text { DCM/MeOH } \\
(1: 1)\end{array}$ & 52 \\
\hline EN00183 & Leaves & Water & 26 \\
\hline EN00296 & Whole plant & $\begin{array}{l}\text { DCM/MeOH } \\
(1: 1)\end{array}$ & 56 \\
\hline EN00296 & Whole plant & DCM & 55 \\
\hline EN00296 & Whole plant & Water & 18 \\
\hline EN00195 & Leaves & Water & 55 \\
\hline EN00195 & Leaves & DCM & 53 \\
\hline EN00195 & Leaves & $\begin{array}{l}\text { DCM/MeOH } \\
(1: 1)\end{array}$ & 38 \\
\hline FP00185 & Whole plant & $\begin{array}{l}\text { DCM/MeOH } \\
(1: 1)\end{array}$ & 87 \\
\hline FP00185 & Whole plant & Water & 40 \\
\hline DS00379 & Leaves & $\begin{array}{l}\text { DCM/MeOH } \\
(1: 1)\end{array}$ & 60 \\
\hline DS00379 & Leaves & Water & 33 \\
\hline BP00646 & Leaves & $\begin{array}{l}\text { DCM/MeOH } \\
(1: 1)\end{array}$ & 50 \\
\hline BP00646 & Twigs & $\begin{array}{l}\text { DCM/MeOH } \\
(1: 1)\end{array}$ & 40 \\
\hline BP00646 & Twigs & Water & 31 \\
\hline BP00646 & Leaves & Water & 30 \\
\hline BР00646 & Fruit & Water & 26 \\
\hline DS00090 & Leaves & $\begin{array}{l}\text { DCM/MeOH } \\
(1: 1)\end{array}$ & 56 \\
\hline DS00090 & Stems & $\begin{array}{l}\mathrm{DCM} / \mathrm{MeOH} \\
(1: 1)\end{array}$ & 31 \\
\hline DS00090 & Stems & Water & 31 \\
\hline DS00090 & Leaves & Water & 16 \\
\hline EN00769 & Leaves & $\begin{array}{l}\mathrm{DCM} / \mathrm{MeOH} \\
(1: 1)\end{array}$ & 81 \\
\hline EN00769 & Fruit & $\begin{array}{l}\mathrm{DCM} / \mathrm{MeOH} \\
(1: 1)\end{array}$ & 40 \\
\hline EN00769 & Leaves & Water & 30 \\
\hline EN00769 & Fruit & Water & 23 \\
\hline MM00008 & Stems & $\begin{array}{l}\mathrm{DCM} / \mathrm{MeOH} \\
(1: 1)\end{array}$ & 45 \\
\hline MM00008 & Roots & $\begin{array}{l}\mathrm{DCM} / \mathrm{MeOH} \\
(1: 1)\end{array}$ & 34 \\
\hline MM00008 & $\begin{array}{l}\text { Leaves and } \\
\text { flowers }\end{array}$ & $\begin{array}{l}\text { DCM/MeOH } \\
(1: 1)\end{array}$ & 31 \\
\hline MM00008 & Roots & Water & 30 \\
\hline MM00008 & Stems & Water & 25 \\
\hline MM00008 & $\begin{array}{l}\text { Leaves and } \\
\text { flowers }\end{array}$ & Water & 25 \\
\hline
\end{tabular}

*exotic to South Africa. 
Table 2 Time lag repellency tests using a selection of active extracts from initial two minute trials

\begin{tabular}{|c|c|c|c|c|c|c|}
\hline \multirow[t]{2}{*}{ Family } & \multirow[t]{2}{*}{ Plant species } & \multirow[t]{2}{*}{ Plant part } & \multirow[t]{2}{*}{ Extraction } & \multicolumn{3}{|c|}{$\begin{array}{c}\text { Repellency\% } \\
\text { (minutes post application) }\end{array}$} \\
\hline & & & & 60 & 120 & 180 \\
\hline Asteraceae & Litogyne gariepina & Roots & DCM & 75 & 52 & 57 \\
\hline Buddlejaceae & Nuxia floribunda & Leaves & $\mathrm{DCM} / \mathrm{MeOH}(1: 1)$ & 43 & 42 & 35 \\
\hline Chenopodiaceae & Chenopodium opulifolium & Roots & Water & 97 & 17 & 30 \\
\hline Lamiaceae & Leucas martinicensis & Leaves & DCM & 60 & 57 & 49 \\
\hline Malvaceae & Sida cordifolia & Whole Plant & $\mathrm{DCM} / \mathrm{MeOH}(1: 1)$ & 40 & 23 & 10 \\
\hline Negative control & & & Distilled water & 10 & 20 & 20 \\
\hline Negative control & & & Acetone & 17 & 20 & 33 \\
\hline Positive control & & & DEET & 100 & 100 & 100 \\
\hline
\end{tabular}

organs from the same species, indicating that volatile components such as essential oils could play a more important role, when formulated appropriately, as plantsourced mosquito repellents. Notable exceptions to this trend were Litogyne gariepina and Chenopodium opulifolium, the root extracts of which showed $>80 \%$ initial repellency.

A limitation of the current study is that volatile compounds were not specifically targeted for mosquito repellency investigation. In this regard, other studies have shown that ethyl acetate extracts of selected plants significantly reduce probing activity of Aedes aegypti [20].

\section{Conclusions}

None of the plants investigated in the current study proved to be a potential candidate for the development of commercial repellents from crude extracts due to their rapid loss of efficacy.

\section{Acknowledgements}

We gratefully acknowledge the Department of Science and Technology of South Africa for the Innovation Fund Grant (Project 31313).

\section{Author details \\ ${ }^{1}$ South African Medical Research Council, 491 Ridge Road, Overport, Durban 4001, South Africa. ${ }^{2}$ Biosciences, CSIR, P.O. Box 395, Pretoria 0002, South Africa. ${ }^{3}$ Ethnobotany Unit, South African National Biodiversity Institute, PO Box 52099, Berea Road 4007/School of Chemistry, University of KwaZulu- Natal, Howard College Campus, Durban 4041, South Africa. ${ }^{4}$ South African Medical Research Council, P.O. Box 19070, Tygerberg 7505, South Africa.}

\begin{abstract}
Authors' contributions
RM was involved in the design of the study and supervising the repellent tests. RG carried out the experiments and was involved in the interpretation of the results. NRC and MN rationally selected suitable plant candidates for investigation. VM and PP were responsible for the extract preparation. NB and PF had coordinated and provided scientific inputs into the entire study. All authors read and approved the final manuscript.
\end{abstract}

\section{Competing interests}

The authors declare that they have no competing interests.

Received: 6 May 2010 Accepted: 28 October 2010 Published: 28 October 2010

\section{References}

1. WHO: WHO Statistics. 2009 [http://www.who.int/whosis/whostat/ EN_WHS09_Table2.pdf].

2. Sharp BL: Anopheles merus Dönitz. Its biology in relation to malaria transmission in Natal. MSc, University of Witwatersrand, Johannesburg; 1983.

3. Mafong EA, Kaplan LA: Insect repellents: What really works? Postgrad Med 1997, 102(63):68-69, 74.

4. Koren G, Matsui D, Bailey B: DEET-based insect repellents: safety implications for children and pregnant and lactating women. Can Med Assoc J 2003, 169:209-212.

5. Fradin MS: Mosquitoes and mosquito repellents: a clinician's guide. Ann Int Med 1998, 128:931-940.

6. Clarkson C, Maharaj VJ, Crouch NR, Grace OM, Pillay P, Matsabisa MG, Bhgawandin N, Smith PJ, Folb PI: In vitro antiplasmodial activity of medicinal plants native to or naturalised in South Africa. $J$ Ethnopharmacol 2004, 92:177-191.

7. Seyoum A, Kabiru EW, Lwande W, Killeen GF, Hassanali A, Knols BG: Repellency of live potted plants against Anopheles gambiae from human baits in semi-field experimental huts. Am J Trop Med Hyg 2002, 67:191-195.

8. Seyoum A, Palsson K, Kung'a S, Kabiru EW, Lwande W, Killeen GF, Hassanali A, Knols BG: Traditional use of mosquito-repellent plants in western Kenya and their evaluation in semi-field experimental huts against Anopheles gambiae: ethnobotanical studies and application by thermal expulsion and direct burning. Trans R Soc Trop Med Hyg 2002, 96:225-231.

9. Jaenson TG, Palsson K, Borg-Karlson AK: Evaluation of extracts and oils of tick-repellent plants from Sweden. Med Vet Entomol 2005, 19:345-352.

10. WHO,CTD/WHOPES/IC/96.1: Protocols for laboratory and field evaluation of Insecticides and Repellents 1996. WHO/HQ Geneva.

11. Vahitha R, Venkatachalam MR, Murugan K, Jebanesan A: Larvicidal efficacy of Pavonia zeylanica L. and Acacia ferruginea D.C. against Culex quinquefasciatus Say. Biores Technol 2002, 82:203-204.

12. Yang YC, Lim MY, Lee HS: Emodin isolated from Cassia obtusifolia (Leguminosae) seed shows larvicidal activity against three mosquito species. J Agr Food Chem 2003, 51:7629-7631.

13. Park BS, Choi WS, Kim JH, Kim KH, Lee SE: Monoterpenes from thyme (Thymus vulgaris) as potential mosquito repellents. J Am Mosq Control Assoc 2005, 21:80-83.

14. Rajkumar S, Jebanesan A: Mosquitocidal activity of octacosane from Moschosma polystachyum L. (Lamiaceae). J Ethnopharmacol 2004, 90:87-89.

15. Roark RC: Some promising insecticidal plants. Econom Bot 1947, 1:437-445

16. Tuetun B, Choochote W, Kanjanapothi D, Rattanachanpichai E, Chaithong U, Chaiwong P, Jitpakdi A, Tippawangkosol P, Riyong D, Pitasawat B: Repellent properties of celery, Apium graveolens L., compared with commercial repellents, against mosquitoes under laboratory and field conditions. Trop Med Int Health 2005, 10:1190-1198.

17. Prajapati V, Tripathi AK, Aggarwal KK, Khanuja SP: Insecticidal, repellent and oviposition-deterrent activity of selected essential oils against Anopheles stephensi, Aedes aegypti and Culex quinquefasciatus. Biores Technol 2005, 96:1749-1757. 
18. Barasa SS, Ndiege IO, Lwande W, Hassanali A: Repellent activities of stereoisomers of p-menthane-3,8-diols against Anopheles gambiae (Diptera: Culicidae). J Med Entomol 2002, 39:736-74.

19. Costantini C, Badolo A, llboudo-Sanogo E: Field evaluation of the efficacy and persistence of insect repellents DEET, IR3535, and KBR 3023 against Anopheles gambiae complex and other Afrotropical vector mosquitoes. Trans R Soc Trop Med Hyg 2004, 98:644-652.

20. Jaenson TG, Palsson K, Borg-Karlson AK: Evaluation of extracts and oils of mosquito (Diptera: Culicidae) repellent plants from Sweden and GuineaBissau. J Med Entomol 2006, 43:113-119.

doi:10.1186/1475-2875-9-301

Cite this article as: Maharaj et al.: Evaluation of selected South African ethnomedicinal plants as mosquito repellents against the Anopheles arabiensis mosquito in a rodent model. Malaria Journal 2010 9:301.

Submit your next manuscript to BioMed Central and take full advantage of:

- Convenient online submission

- Thorough peer review

- No space constraints or color figure charges

- Immediate publication on acceptance

- Inclusion in PubMed, CAS, Scopus and Google Scholar

- Research which is freely available for redistribution

Submit your manuscript at www.biomedcentral.com/submit 